\title{
SIMULASI PRODUKSI E-BIKE ITSB MODEL PERTAMA
}

\author{
Wildan Aulia, Oemar Handojo \\ Desain Produk, Institut Teknologi dan Sains Bandung \\ wildan@itsb.ac.id
}

\begin{abstract}
Abstrak
Program Studi Desain Produk ITSB, melalui Tugas Akhir mahasiswa Prodi DP, telah melakukan inovasi konsep scootpad bertenaga surya yang dieksekusi hingga tahap prototipe dengan nama E-Bike ITSB. Untuk mendistribusikan hasil pengembangan kepada masyarakat, Pusat Desain Produk Industri yang berada di bawah Lembaga Penelitian dan Pengabdian kepada Masyarakat (LPPM) ITSB melakukan persiapan tahap produksi E-Bike ITSB untuk memperoleh standar produk yang baik sehingga layak didistribusikan kepada pengguna. Hal ini mendesak untuk dilakukan karena keberadaan kendaraan ini telah mendapat sambutan positif dari masyarakat melalui beberapa publikasi nasional di media cetak dan televisi. Secara khusus, beberapa pihak menunjukkan keberminatan terhadap kendaraan ini untuk digunakan sebagai kendaraan commuter di kawasan terpadu. Persiapan produksi dilakukan melalui metode comprehensive prototyping, yaitu menguji produk dalam skala utuh yang dioperasikan dalam kondisi maksimal serta disimulasikan dalam tahap in line produksi untuk menguji aspek kedayagunaan serta kesiapan rantai pasol dan produksi. Penelitian menghasilkan lima unit E-Bike ITSB. Kerjasama rekanan dan resources untuk pemenuhan komponen kelistrikan dan pembuatan rangka juga mulai terjalin. Kegiatan ini dapat diklaim telah meningkatkan kesiapan inovasi E-Bike ITSB menjadi level 5 karena rantai pasok komponen dan rangka sudah teridentifikasi dan mulai terbangun.
\end{abstract}

Kata kunci: comprehensive prototyping, rantai pasok, simulasi, produksi

\begin{abstract}
The ITSB Product Design Study Program, through the Final Project of DP Study Program students, has innovated the concept of a solar powered scootpad which was executed until the prototype stage with the name E-Bike ITSB. To distribute development results to the community, the Industrial Product Design Center under the ITSB Institute for Research and Community Service (LPPM) prepares the ITSB E-Bike production stage to obtain good product standards so that it is feasible to be distributed to users. This is urgent to do because the existence of this vehicle has received a positive response from the public through several national publications in print and television media. In particular, several parties expressed interest in this vehicle to be used as a commuter vehicle in integrated areas. Production preparation is carried out through a comprehensive prototyping method, which is to test products on a full scale that are operated in maximum conditions and simulated in the in-line production stage to test aspects of efficiency and supply chain readiness and production. The research resulted in five ITSB E-Bike units. Collaboration with partners and resources for the fulfillment of electrical components and making frames has also begun to be established. This activity can be claimed to have increased the readiness of ITSB E-Bike innovation to level 5 because the supply chain of components and frames has been identified and is starting to build.
\end{abstract}

Keywords: comprehensive prototyping, rantai pasok, simulasi, produksi

\section{Pendahuluan}

Kendaraan roda dua bertenaga surya (solar cell), E-Bike ITSB, yang dirancang oleh Giasa Lutfiah dan dikembangkan Program Studi Desain Produk ITSB merupakan salah satu inovasi kendaraan ramah lingkungan yang awalnya dirancang sebagai kendaraan commuter di lingkungan kampus ITSB [1][2]. Hasil publikasi pertama kendaraan roda dua bertenaga surya ITSB, baik yang dilakukan oleh Institusi melalui media masa elektronik, televisi dan cetak; maupun yang dilakukan oleh Prodi DP ITSB melalui seminar, telah menunjukkan keberminatan masyarakat yang cukup tinggi. Hal ini memerlukan respon yang cepat agar keberadaan kendaraan tersebut masih relevan dengan kebutuhan masyarakat [3]. E-Bike ITSB secara khusus telah mendapatkan tanggapan positif dari Kemenristekdikti. E-Bike ITSB telah masuk ke dalam directory Produk Inovasi Indonesia tahun 2016. Pada 11 Juli tahun 2018, Prodi Desain Produk ITSB diundang oleh

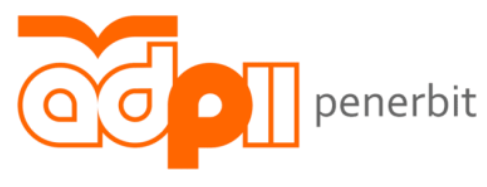

Penerbit Aliansi Desainer Produk Industri Indonesia 
Kemenristekdikti untuk mengikuti Focus Group Discussion mengenai rantai pasok komersialisasi produk Perusahaan Pemula Berbasis Teknologi/PPBT di bidang energi. Hasil FGD menunjukkan bahwa tingkat kesiapan inovasi (katsinov) E-Bike ITSB masih berada di level 4. Hal ini dikarenakan komponen E-Bike ITSB masih bergantung pada komponen sepeda listrik tipe tertentu sehingga keberlangsungan produk menjadi tidak aman (secure). Sebagai tanggapan terhadap hal tersebut, tim peneliti memandang perlu untuk melakukan simulasi produksi terhadap E-Bike ITSB agar dapat menyusun skema produksi dan rantai pasok sehingga level tingkat kesiapan inovasi dapat dinaikkan.

\section{Metodologi}

Studi dilakukan melalui dua pendekatan, yaitu pendekatan desain dan pendekatan manufaktur. Pendekatan desain dilakukan untuk mengukur daya guna produk; sedangkan pendekatan manufaktur akan mensimulasi pengadaan barang, menyiapkan dan menyempurnakan proses pabrikasi dan perakitan, melakukan briefing teknis produksi serta menyempurnakan proses QC/penjaminan mutu [4][5]. Pengujian prototipe dilakukan melalui metode comprehensive prototyping, yaitu menguji produk dalam skala utuh yang dioperasikan dalam kondisi maksimal serta disimulasikan dalam tahap in line produksi. Berikut adalah bagan alur pengujian yang akan dilakukan:
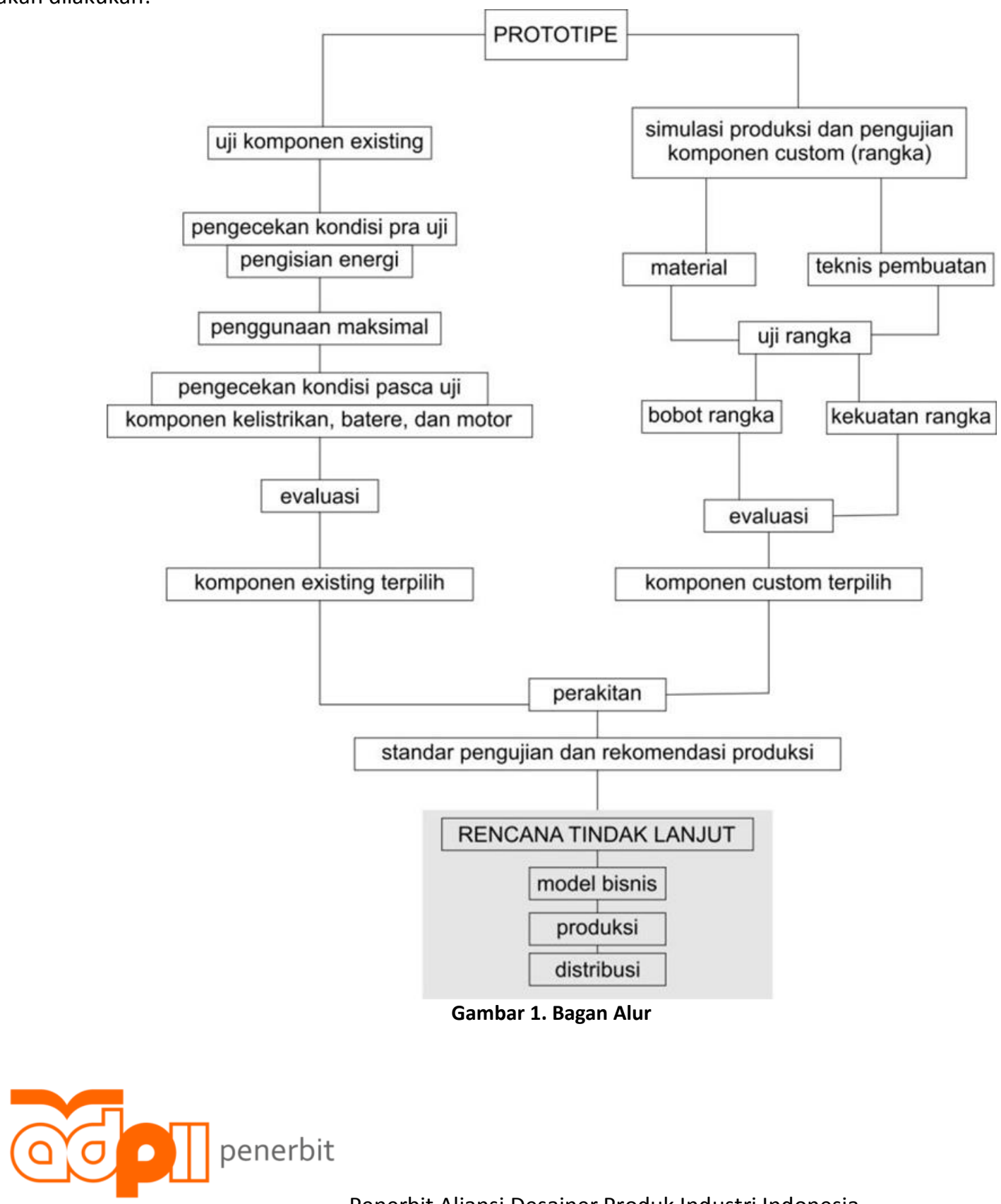

Penerbit Aliansi Desainer Produk Industri Indonesia 
Rangka kendaraan disimulasikan dalam tahap produksi untuk memperoleh teknik pembuatan yang baik dalam skala minimum order sehingga dapat diproyeksikan biaya pembuatan kendaraan dalam skala mass produksi. Perbaikan desain yang bersifat minor serta pemilihan material dan komponen sepeda yang lebih baik dilakukan setelah mendapatkan hasil pengujian. Pengujian E-Bike ITSB dengan metode comprehensive prototyping memerlukan setidaknya lima prototipe awal yang digunakan untuk menguji:

1. Kekuatan rangka dan komponen custom dalam penggunaan maksimal dengan mengendarainya sesuai lingkungan di mana produk akan digunakan.

2. Kualitas existing part dalam penggunaan maksimal dengan mengendarainya sesuai lingkungan di mana produk akan digunakan.

3. Daya tahan produk untuk diuji dalam kondisi ekstrem yang terprediksi seperti tabrakan, terjatuh, melintasi medan yang sangat buruk, dan proses pengiriman barang yang tidak baik.

4. Simulasi produksi dalam skala minimum order.

\section{Pembahasan}

\subsection{Persiapan dan Simulasi}

Sebelum masuk pembuatan rangka, prototipe awal yang telah ada dibuat kembali sebagai simulasi produksi. Hasil simulasi disesuaikan dengan sumber daya yang dimiliki mitra pembuat rangka yang akan ditugaskan untuk membuat 10 rangka.

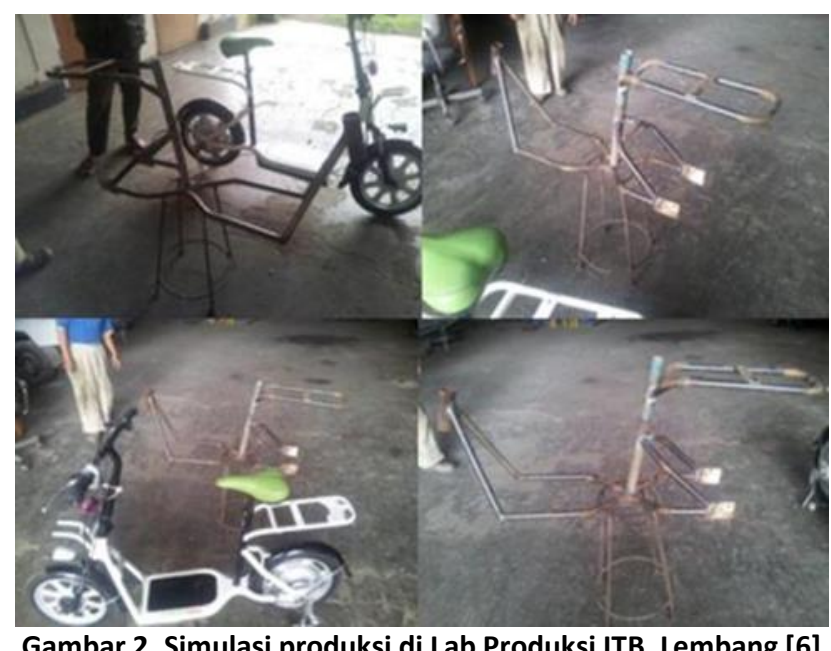

Komponen disediakan secara bertahap dan dilakukan selama enam bulan. Komponen kelistrikan dan asesoris didatangkan dari China dengan langsung mencari sumber pembuat komponen untuk menghindari ketergantungan komponen sepeda listrik tipe tertentu. Hal ini penting agar keberlanjutan produk dapat dijaga. Berikut adalah komponen yang dipilih dan diusulkan menjadi standar komponen E-bike ITSB:

Komponen custom:

1. Rangka

2. Handle bar

3. Frame solar cell

4. Alas angkut barang

5. Pin stopper hub belakang

Komponen semi customize:

1. Tiang post handle bar lipat - black dove dimodifikasi pada bagian bos stir

2. Kunci panel dimodifikasi pada sudut pin kuncian

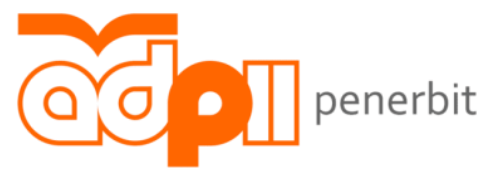


Komponen kelistrikan:

1. BLDC electric motor rear hub + front hub 24V $350 \mathrm{~W}$ lengkap dengan ban untuk rear hub dan front hub.

2. kontroler set 24V 350W dan indikator battery + horn + front lamp

3. grip twister kanan kiri; handle brake kanan kiri

4. lithium ion battery $24 \mathrm{~V} 10 \mathrm{aH}+$ charger + custom casing

5. Solar Panel Flexy 18V10W High Performance

6. Solar System $2 \times 2.5$ NYYHY Outdoor Cables

7. Solar Charger Controller 24V/10A/50WP

8. Electric System Cable Red-Black

9. Socket MF, Schoen, Plug and Junction

10. Tin Wire Solder, Heatshrink Tube, Ties, Seal

Komponen non elektrik dan asesoris:

1. Spatbor depan R16 2.25

2. Spatbor belakang R16 2.25

3. Saddle jok pegas

4. $\quad$ Front fork shockbreaker R16 2.25

5. Rem depan dan kanvas rem

6. Rem belakang dan kanvas rem

7. Standar belakang single

8. Komstir set upper-bottom ball bearing

9. Kabel rem belakang dan rem depan

10. Reflektor

11. Jaring helm

\subsection{Produksi Rangka dalam Jumlah Minimal}

Dalam kondisi maksimal, pembuatan 10 rangka sebetulnya dapat diselesaikan dalam waktu dua minggu. Namun karena beberapa program kerja yang tidak dapat dieksekusi sesuai targetnya, maka pembuatan rangka tertahan cukup lama sehingga rangka menjadi berkarat. Akibat rangka yang berkarat, maka proses powder coating menjadi tidak maksimal. Hasil pengecatan terlihat bertekstur di beberapa bagian akibat udara yang mendorong cat sebagai reaksi karat terhadap panas di saat proses powder coating.

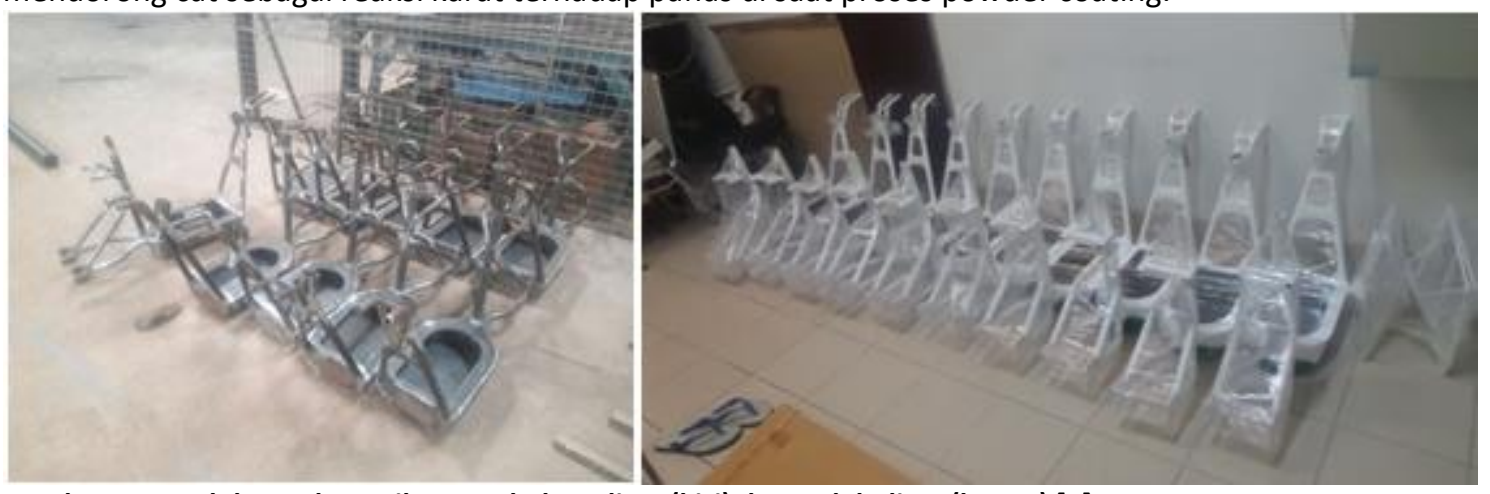

Gambar 3. Sepuluh rangka E-Bike yang belum dicat (kiri) dan sudah dicat (kanan) [6]

Hasil akhir pembuatan 10 rangka menunjukkan bahwa workshop bidang konstruksi dan teknik tidak memiliki keahlian yang cukup untuk memproduksi rangka sepeda. Hal ini dimungkinkan dari tingkat kesulitan konstruksi dan detail rangka sepeda yang jauh lebih rumit daripada produk konstruksi. Akibatnya, setiap rangka tidak seragam. Beberapa ukuran bagian rangka tidak sama seperti sudut bar post (rake angle) dan seat post, dudukan bagasi, dan stang. Ukuran yang berbeda tidak bisa ditoleransi karena perbedaannya terlalu jauh, khususnya sudut bar post (rake angle) yang terlalu landai sehingga ruang abdomen pengendara terlalu sempit dan produk menjadi tidak ergonomis.

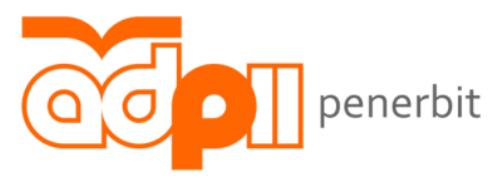

Penerbit Aliansi Desainer Produk Industri Indonesia 

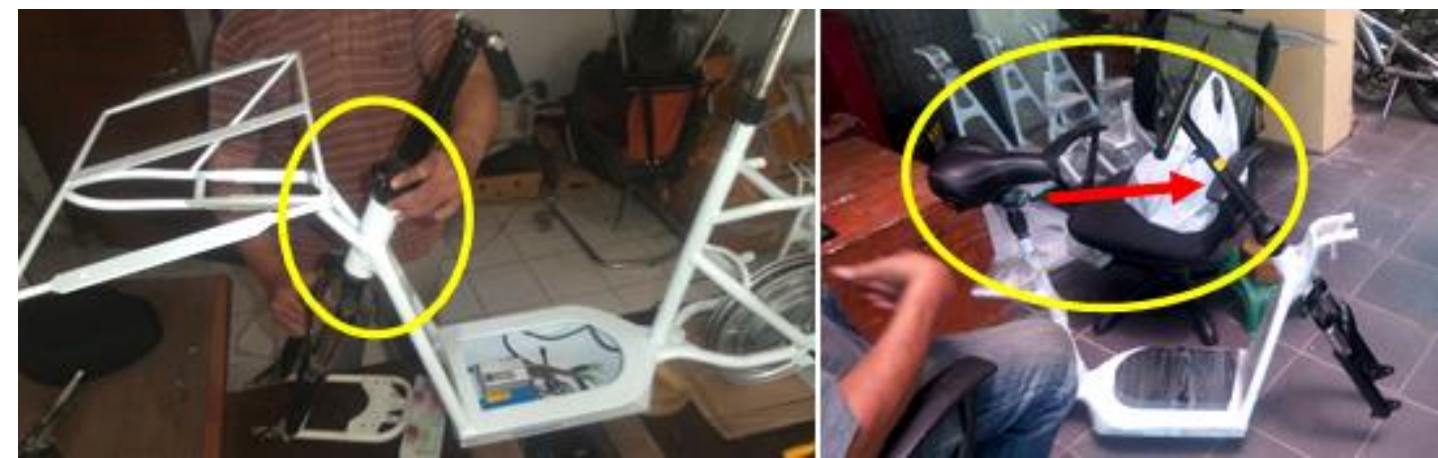

Gambar 4. Komponen stang yang memerlukan penyesuaian karena Sudut bar post yang tidak center (kiri) dan ruang abdomen pengendara yang terlalu sempit akibat dari sudut dudukan bar post yang terlalu landai. [6]

\subsection{Penyesuaian Komponen dan Perakitan}

Perbaikan yang dilakukan adalah menyetel kembali rangka yang sudah ada di Lab Produksi ITB, terutama untuk pengerjaan halus, yaitu:

1. Menyejajarkan dudukan frame solar panel,

2. Memperbesar diameter dudukan seat post dan kom stir,

3. Memotong dudukan seat post,

4. Menyambung dan membuat kembali dudukan bagasi

5. Membuat stang yang sesuai dengan sudut bar post yang terlalu landai.

Beberapa komponen perlu dirancang ulang dan diproduksi terpisah, yaitu stang, frame solar panel dan bagasi. Selain itu seat post menggunakan pipa ukuran 26 dan dijadikan sebagai standar produk.

Proses perakitan memberikan input mengenai perbaikan dan penyesuaian beberapa komponen serta gambaran in line produksi. Simulasi yang dilakukan di Lab Produksi ITB adalah simulasi produksi skala industri kecil menengah. Perakitan dilakukan secara manual dengan tiga orang pekerja. Dengan penyesuaian yang cukup banyak, lima E-Bike ITSB dirakit dalam waktu enam hari. Bila penyesuaian sudah distandarkan, maka waktu perakitan bisa diakselerasi tiga kali lipat.
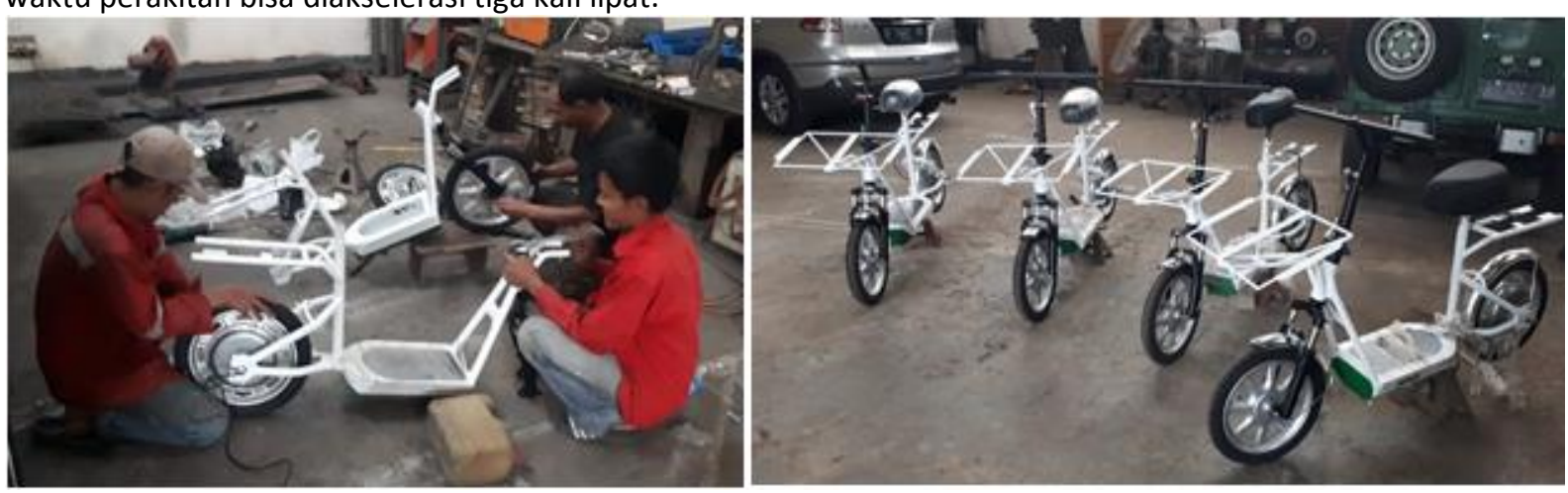

Gambar 5. Proses perakitan dan hasilnya [6]

Hasil perakitan komponen utama kemudian dilanjutkan dengan perakitan komponen asesoris dan kelistrikan. Diagram elektrical dan pemasangan rangkaian kelistrikan dilakukan oleh teknisi khusus sepeda listrik. Kelistrikan dipasang setelah semua komponen non elektrik terpasang. 

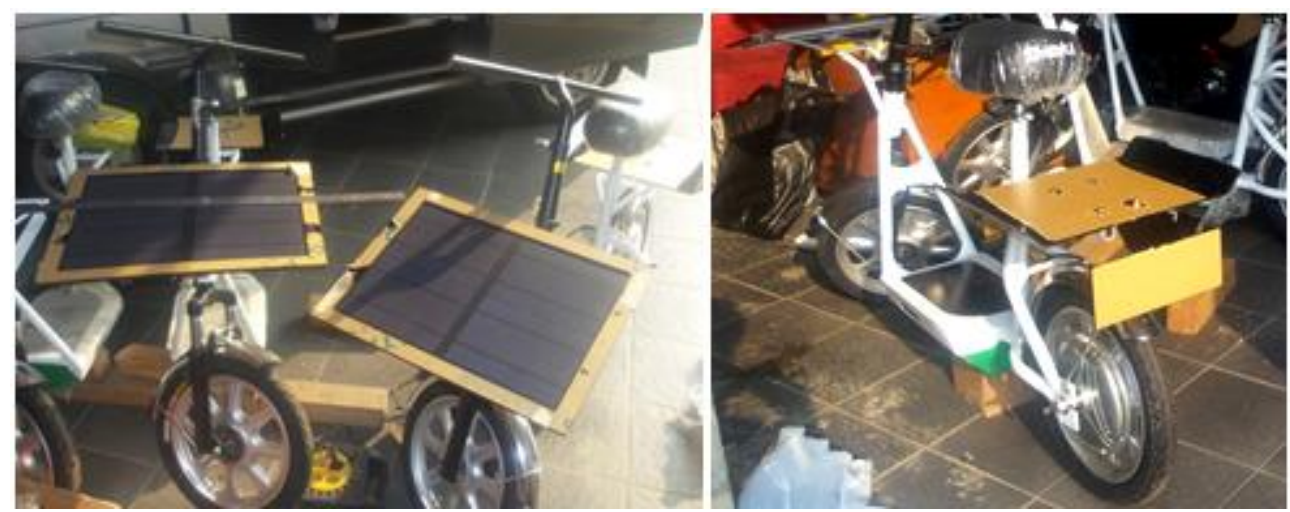

Gambar 6. Rancangan frame solar panel, stang dan bagasi yang sudah terpasang pada rangka E-Bike ITSB [6]
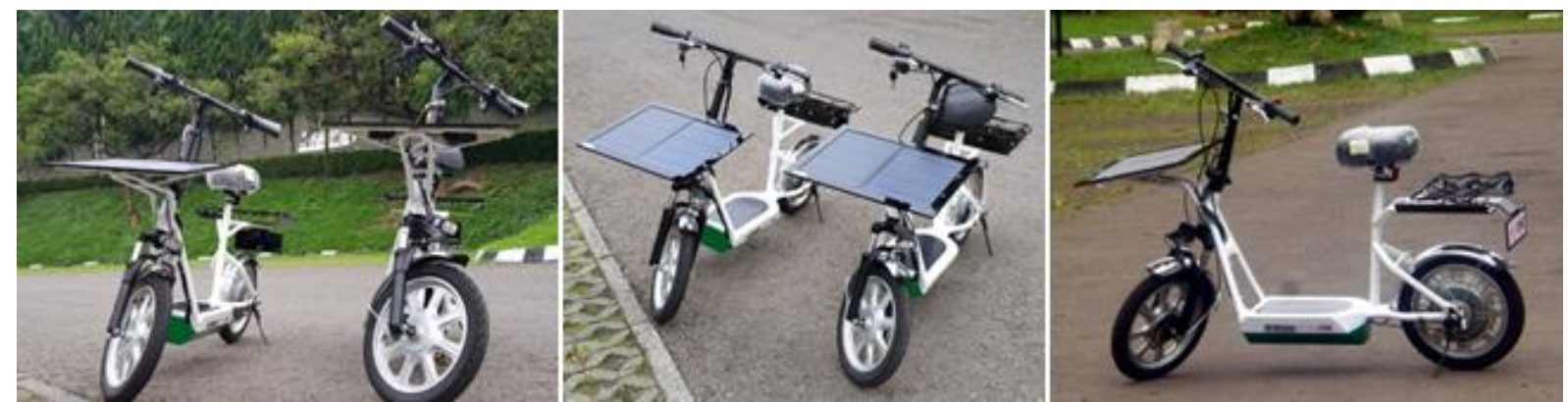

Gambar 7. E-Bike ITSB yang sudah selesai [6]

\subsection{Hasil Pengujian}

Dua E-Bike ITSB diselesaikan pada tanggal 8 Desember 2019. Pengujian kendaraan menghasilkan beberapa catatan penting, yaitu:

1. Beban maksimal $60 \mathrm{~kg}$ yang dapat diangkut oleh E-bike adalah $60 \mathrm{~kg}$. Top speed E-Bike adalah antara $15-20 \mathrm{~km} / \mathrm{jam}$. Sistem kelistrikan $24 \mathrm{~V}$ tidak maksimal. Motor mudah kelebihan beban. Untuk menghindari motor terbakar, $\mathrm{MCB}$ akan memutus sendiri arus listrik saat beban berlebih. diletakkan di dalam kompartemen batere. Kriteria beban berlebih bagi E-Bike ITSB adalah:
a. Beban di atas $60 \mathrm{~kg}$.
b. Full throttle terlalu lama (melebihi 10 menit). MCB 10 sudah dapat mengatasi hal ini.
c. Jalan menanjak dengan jauh lebih dari $20 \mathrm{~m}$ dan bersudut lebih dari $20^{\circ}$.
d. Jalan tidak rata.

Perbaikan yang harus dilakukan:
a. Upgrade sistem kelistrikan ke sistem $36 \mathrm{~V}$ untuk meningkatkan torsi.
b. Upgrade motor minimal ke 500 watt untuk meningkatkan kecepatan.
c. Upgrade kapasitas batere karena penyesuaian voltase yang dipilih.
d. Upgrade kontroler untuk meningkatkan efektifitas konversi energi dan efisiensi penggunaan energi. Hal ini sangat direkomendasikan agar optimasi kelistrikan menjadi lebih baik.

2. E-Bike ITSB belum melewati uji dalam penggunaan maksimal. Namun dari beberapa kali percobaan berkendara, dapat diberikan catatan sebagai berikut:

a. $\quad$ Frame solar panel perlu dipertimbangkan untuk dipertebal atau diberi skrup lebih banyak karena cenderung bergetar saat melaju di jalanan tidak rata. Juga rentan pecah saat EBike terjatuh.

b. Tutup kompartemen kelistrikan sebaiknya menggunakan sistem skrup dan diberi seal untuk mencegah air masuk ke dalam kompartemen.

c. Kondisi frame yang tidak baik belum menunjukkan kegagalan pada sistem berkendara EBike. Usia frame harus menjadi perhatian karena frame tidak dibuat dengan sistem roll sehingga secara kekuatan struktur tidak terlalu baik.

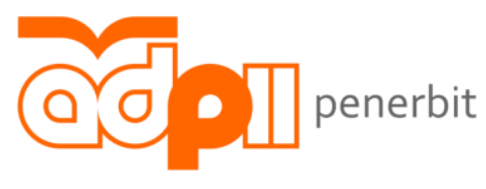

Penerbit Aliansi Desainer Produk Industri Indonesia 
d. Ergonomi sudah baik. Pengendara dapat nyaman mengendarai E-Bike setelah stang dirancang kembali dengan mendorongnya lebih jauh ke depan.

e. Bagasi cukup besar, dapat mengangkut objek berdimensi bounding box $30 \mathrm{~cm} \times 30 \mathrm{~cm} \times$ $30 \mathrm{~cm}$

3. Catatan pada rangka adalah:

a. Rangka tidak dapat diproduksi di workshop bidang konstruksi. Disarankan untuk diproduksi secara manufaktur atau di bengkel modifikasi.

b. Desain rangka harus mengalami penyempurnaan terlebih dahulu sesuai standar desain rangka kendaraan sebelum dieksekusi.

c. Jig harus dibuat dengan pendekatan skala manufaktur.

d. Toleransi ukuran harus dapat mendekati nol untuk menghindari kostumisasi yang terlalu banyak pada rangka maupun komponen.

e. Perakitan sebaiknya dilakukan dalam line perakitan yang baik sehingga memudahkan pengerjaan (PPIC).

f. Kunci kompartemen batere sebaiknya dihilangkan karena sistem kuncian tidak terlalu dibutuhkan. Sistem kunci tutup kompartemen malah lebih membutuhkan biaya karena harus menyediakan komponen kunci sekaligus memodifikasinya.

Perbaikan rangka dan percobaan membuatnya dalam skala manufaktur sudah mulai dilakukan di lab Pengelasan dan Fabrikasi ITSB.
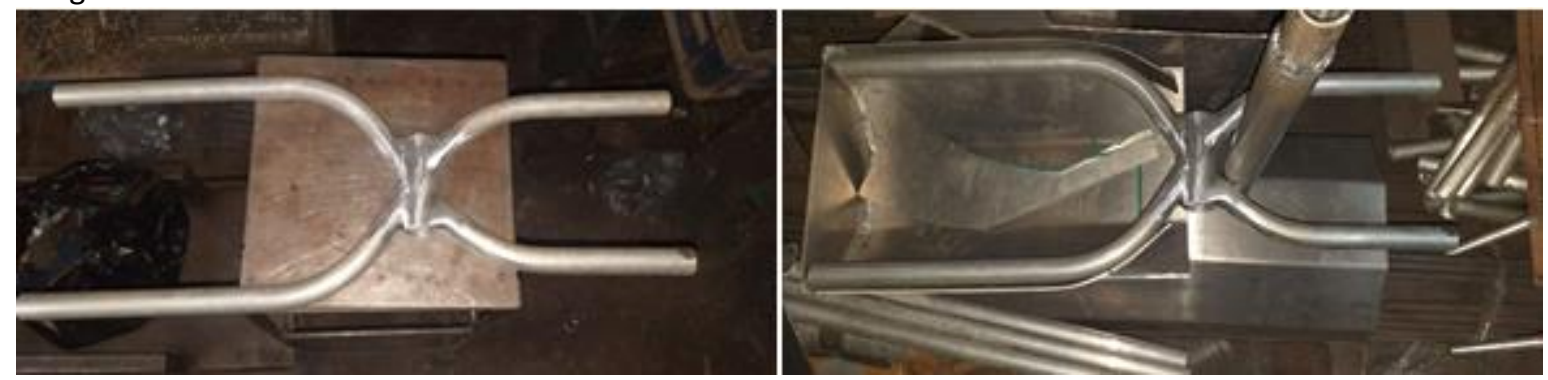

Gambar 8. Percobaan pembuatan rangka skala manufaktur di lab Pengelasan dan Fabrikasi ITSB. [7]

\section{Kesimpulan}

Proses simulasi produksi sudah cukup untuk memberikan gambaran in line produksi dalam skala manufaktur. Hal-hal yang harus menjadi perhatian adalah:

1. Pembuatan rangka sebaiknya berdasar pada komponen yang sudah dipilih, sehingga tidak memerlukan penyesuaian rangka dan komponen.

2. Line produksi dapat dibagi ke dalam empat tahap utama, yaitu:

a. pembuatan rangka,

b. pemasangan komponen non elektrik,

c. pemasangan kelistrikan,

d. Quality Control (QC).

Tahapan ini sebaiknya dibuat dalam skema ban berjalan.

3. Standar kualitas komponen harus betul-betul diperhatikan dan diseragamkan.

4. Rangka harus digambar ulang dengan mengacu kepada komponen existing yang dipilih. Rangka yang telah digambar ulang disarankan untuk dijadikan standar E-Bike ITSB.

5. Hasil simulasi menunjukkan bahwa biaya satu E-Bike dalam skala pembuatan 10 unit berada di harga 14,7 juta rupiah.

6. Tingkat kesiapan inovasi E-Bike ITSB dapat diklaim sudah berada di level 5 karena rantai pasok komponen dan rangka sudah teridentifikasi dan mulai terbangun. 


\section{Ucapan Terima Kasih}

Tim peneliti mengucapkan terima kasih kepada LPPM ITSB selaku lembaga yang membawahi kegiatan ini; PT Yatra Buana Fajar, Bekasi selaku pembuat rangka; PT Zahtra Elektrik Nusantara, Bandung selaku penyedia komponen E-Bike dan pemasangan kelistrikan; Lab Produksi ITB, Lembang selaku penyedia tempat simulasi awal, penyempurnaan rangka dan perakitan; serta CV Arana Adi Setia selaku penyedia tempat penghitungan pembuatan rangka dalam skala manufaktur.

\section{Referensi}

[1] Handoyo, Oemar \& Lutfiah, Giasa. 2016. Desain Kendaraan Roda Dua Bertenaga Matahari.Proceedings SENIATI 2016, Green Technology Innovation, 6 Februari 2016, hal. D.25-1 - D.25-6, ISSN: 2085-4218. Malang: Fakultas Teknologi Industri Institut Teknologi Nasional Malang.

[2] Lutfiah, Giasa. 2015. Pengembangan Desain Kendaraan Roda Dua Bertenaga Matahari. Karya Tugas Akhir. Bekasi, Kota Deltamas: Program Studi Desain Produk Industri, Institut Teknologi dan Sains Bandung.

[3] Media Monitoring Sinarmas. 2015. Sepeda Solar Cell ITSB. Jakarta: Sinarmas.

[4] Ulrich, Karl T., \& Eppinger, Steven D. 2008. Product Design and Development. New York: McGraw Hill.

[5] Thompson, Rob. 2012. Manufacturing Processes For Design Professionals. London: Thames \& Hudson.

[6] Aulia, Wildan. 2019. Pembuatan Prototype dan Simulasi Produksi E-Bike ITSB. Laporan Akhir Penelitian Internal Dosen Tetap ITSB. Bekasi: Perpustakaan ITSB, https://repository.itsb.ac.id/

[7] Arsip foto laporan kemajuan pengerjaan rangka E-Bike ITSB. 2020. Bekasi: Institut Teknologi Sains Bandung. 